\title{
COMMERCIAL REAL ESTATE RETURN DISTRIBUTIONS: A REVIEW OF LITERATURE AND EMPIRICAL EVIDENCE ${ }^{1}$
}

\author{
COLIN LIZIERI and CHARLES WARD \\ Version of 11 January 2000, comments welcome.
}

In this paper, we consider the distribution of returns in the commercial real estate market. By commercial real estate, we mean land and buildings owned by one party (an institutional investor, a specialist property company or private individuals) and let to another party. Such real estate includes office, retail and industrial properties let to firms and apartments and homes let to private individuals, this last category being conspicuously absent from UK institutional investment portfolios. We, thus, distinguish commercial real estate from private residential markets, from owneroccupied corporate real estate and from loans secured on property (such as mortgage backed securities). We focus largely on the UK and US markets, reflecting both available data and existing research. Initially we discuss definitional issues and measurement problems. We then review the published literature on return distributions and return generating processes. Next, empirical evidence from the UK market is presented. Finally, we consider the implications of the findings for mixed asset portfolio strategies.

\section{Definitional and Measurement Issues}

Within the real estate literature, research usually distinguishes between the private and public real estate markets. The private (or direct) market consists of buildings owned and managed by investors or their agents. Trans actions are typically by private treaty, although lower quality ("secondary") property may be sold by auction. The public (or indirect) market consists of the securities of firms specialising in the management or trading of property: property companies in the UK, real estate investment trusts (REITs) and real estate operating companies (REOCs) in the US. There are also some corporate or institutional vehicles that combine characteristics of both markets -

\footnotetext{
${ }^{1}$ This paper forms the basis of a chapter in Return Distributions in Finance, edited by John Knight \& Steven Satchell, published by Butterworth Heinemann in 2000. We are grateful to the editors for permission to publish this preliminary version.
} 
property unit trusts and commingled real estate funds for example. The characteristics of each market are considered further below.

The commercial real estate market forms a small but significant part of institutional and private investors' portfolios. Despite this, real estate has been a comparatively neglected topic in the financial economics literature. There are a number of reasons for this lacuna. First, commercial real estate has a number of characteristics that distinguish it from other asset markets. Properties, because of their locational fixity and size differentiation, rarely have near-perfect substitutes. Thus, the market is characterised by heterogeneity. This has implications for portfolio construction, particularly in the direct market where problems are exacerbated by large lot size and high transaction costs. Further, in the private market, the absence of a transparent marketplace leads to asymmetric information and the absence of transaction-based data. Reported returns are frequently based on appraisals of value rather than sales information. This has important implications for the modelling of returns distributions, as we will see.

The distinct institutional structure of the real estate market has led to the development and preservation of analytic techniques and terminology which differ from those found in other asset markets. This is particularly true in the UK, where the Royal Institution of Chartered Surveyors holds a quasi-monopolistic position over professional advice (and education) in the real estate field. The RICS lays down a set of definitions and practice notes that professional members must follow if they are to avoid potential professional negligence claims. These enshrine certain practices and techniques, a process reinforced by court and tribunal decisions and precedents.

The estimation of returns in the private real estate market is much more complex than in bond and equity markets. The basic components are, of course, income return and capital growth. Each presents particular problems in calculation.

The income return comes from the rent paid by the tenant. The return must account for the timing of payments (typically quarterly in advance in the UK, monthly in the US) and for the cost of rent collection. The latter is problematic and there is no common standard for calculation of net operating income. Direct costs (maintenance, 
repairs and insurance not chargeable to the tenant, professional fees, marketing charges for example) are clear, but the indirect costs of managing the property may be obscured. This is particularly true for properties held and managed by an institution or property company with an in-house management function.

The estimation of the capital gain component of return is particularly difficult in real estate. Long holding periods and infrequent transactions mean that the capital value is an estimate provided in-house or by an external appraiser or valuer. There is insufficient space to discuss all the appraisal issues relating to property (for a review, see Ball et al. 1998). Because the transaction market is so thin, the valuer has to resort to a formalised version of what is, essentially, a dividend discount model of valuation. He or she must consider the current and future income stream, the security of that income (that is, the probability of the tenant defaulting or vacating and the probability of securing a new letting), the investment demand for the property (which will include consensus estimates both of future market rental growth and of the covenant strength of the tenant), the legal terms of the agreement between landlord and tenant and any specific risk factors relating to the building. These risk factors, typically, are incorporated into a single "initial yield" or capitalisation rate. Asset heterogeneity and thin transaction markets means that the appraisal utilises a very limited current information set.

Two consequences of this process are important. First, the appraisal process creates uncertainty as to the true value, and hence about both components of the return. There have been a number of studies concerning valuation and appraisal accuracy ${ }^{2}$. These are not conclusive but cast doubt on validity of conclusions drawn from appraisal based data. That said, it is the appraisal-based returns that are used to measure fund performance and fund $m$ anager added value. Thus there is a case for using unadjusted returns. Second, because appraisers are faced with a limited information set, it is suggested that they use evidence over a time window around (but generally preceding) the notional date of the valuation and that they adjust prior valuations in the light of new evidence by an intuitive process of Bayesian adjustment. The first gives rise to temporal aggregation effects, the second to an auto-regressive or 
exponential smoothing effect ${ }^{3}$. The consensus position from published research is that appraisal smoothing reduces the measured volatility of real estate. Further, appraisals may lag turning points and understate both peaks and troughs.

Unitised property investment vehicles such as Property Unit Trusts are similarly liable to appraisal uncertainty, since the value of each unit (and, hence, the notional return) is determined by independent property valuers. For larger funds, diversification may reduce this valuation uncertainty - or at least its random component. Additional uncertainty arises in poor market conditions as fund managers widen spreads and seek to defer redemption, reducing liquidity.

Performance in the public market is easier to measure, since share prices and dividend information are readily available. Two issues are worth mentioning. First, many REITs and property companies have relatively small market capitalisations and, in common with other small cap stocks, have consequent larger bid-ask spreads than large cap stocks and potential problems of illiquidity in difficult market conditions. Second, care must be taken in using published sector indices, in that very dissimilar types of firms may be included. For example, in the UK, many property sector indices include property investment companies, speculative developer-traders and property service providers, while the widely-used US National Association of Real Estate Investment Trusts (NAREIT) index (see below) includes both property-owning and mortgage REITs. Although information on returns is readily available, investors are faced with the same appraisal problem as in the private market in attempting to estimate the net asset value of firms.

In the United States, the most frequently used index of private commercial real estate performance is that produced by the National Council for Real Estate Investment Fiduciaries (NCREIF). NCREIF provide income, capital and total returns disaggregated by sector and region based on a sample of institutional-owned properties valued at \$73billion as at 1999 Q2. The data runs from 1977 Q4 and is available on a quarterly basis. Many of the properties are only valued on an annual

\footnotetext{
${ }^{2}$ For the UK, see, for example, Adair et al. (1996); Brown (1992); Lizieri and Venmore-Rowland (1993); Matysiak and Wang (1995).
} 
basis, creating seasonality in the data. The lack of high frequency data is a particular problem in real estate, the high cost of appraisal precluding frequent reporting. In the United Kingdom, an equivalent benchmark performance service is provided by Investment Property Databank (IPD). The IPD databank contains property valued at $£ 75$ bn (\$126bn) as at December 1998. Annual performance, again separable into sectors and regions, is available from 1980. IPD have produced a monthly index since December 1986. However, the properties in that index are predominantly held in unit trusts and, hence, may not be representative of the total institutional markets. A number of commercial agents produce similar appraisal based indices. However, since these tend to contain small numbers of properties and, hence, high levels of specific risk, they cannot be considered as reliable indicators of market performance.

An alternative source of private returns information is to create synthetic returns from published rent and capitalisation rate (or yield) data. In the UK, CB Hillier Parker produce a regular (quarterly) series of market rents and yields for hypothetical, beacon properties in a number of towns. These are then aggregated to produce regional and national indices. Calculated on a quarterly or annual basis, such returns will overstate achievable investment performance, since they ignore the impact of the contractual terms of leases. However, they will be more responsive to market conditions than portfolio-based indices and are, thus, useful as barometers of change. In the US, the American Council of Life Insurers publish capitalization rates which can be combined with NCREIF rent data to produce a similar barometer (see, e.g. Ling and Naranjo, 1999).

Price and return indices for public market real estate can be obtained readily from standard sources: the FTSE in the UK, CRSP in the US, Datastream, for example. Care must be taken with these series; researchers must be mindful of composition changes and survivorship bias. For US real estate investment trusts, the NAREIT index is commonly used. The explosive growth of REITs in the 1990s (increasing from \$ 9 bn in 1990 to \$44bn in 1994 and peaking in 1997 at \$140bn) and the changing nature of the REIT market once again requires a health warning to be placed on the data. Furthermore, the overall REIT index includes mortgage REITs, hybrid REITs

\footnotetext{
${ }^{3}$ Discussions may be found in Barkham and Geltner (1994, 1995); Blundell and Ward (1987); Brown
} 
and heal thcare REITs as well as commercial property equity REITs. For international markets, Global Property Research, based in the Netherlands, publish country and regional-continental indices of property company performance.

In comparing public and private real estate markets, analysts and researchers must be aware of many issues: the different nature of index construction; uncertainty relating to appraisal-based private returns; appraisal-induced smoothing and serial correlation; the impact of gearing (leverage) on public-market returns, for example. Furthermore, international comparisons must be mindful of differences in the nature of the investment vehicle. For example, REITs are a pass through, income distribution vehicle while UK property companies pay dividends and may retain earnings for investment. This will alter the relationship between the public property stock, other equities and the underlying real estate asset.

We have dwelt at some length on these definitional and measurement issues to emphasise that real estate is "different" and that caution must be exercised in utilising published performance indices. Analysis and research must be mindful of the institutional structure of the market in order to avoid misuse of statistics and misleading interpretations of data. Next we examine the structure of returns, turning first to the direct, private, market, before considering patterns and distributions in the public market and the linkage between the two markets.

\section{The Private, Direct Real Estate Market}

As the previous section implied analysis of return distributions in the direct real estate market is hampered by the low frequency of data and uncertainty concerning the validity of appraisal based returns. Nonetheless, concern has been expressed about the distributional characteristics of real estate returns and the possible impact of nonnormality. In addition to attempts to "desmooth" property returns (that is, to attempt to remove serial correlation and aggregation effects to extract the "true" market signal), a number of authors have tested for normality. The results point both to peaked, fat-tailed distributions and, more tentatively, to skewness.

(1991); Geltner (1991); Quan and Quigley (1991) and Ross and Zisler (1991). 
Young and Graff (1995) examine returns distributions for US institutional private real estate as captured in the NCREIF database. They decompose annual returns data for individual properties (grouped by type of property) over the period 1980-1992 into two components - the mean return for a property type in any one year and a residual return for the individual property in that year. The residual series is taken as representing the asset-specific risk for that year. They then use the methodology suggested by McCulloch to fit stable distributions to the residual series and estimate the parameters of the characteristic function. The $\alpha$ parameter for the whole sample, at 1.48 is significantly below the value of 2.0 that characterises a normal distribution. This result held for the great majority of years and property types. The $\beta$ parameters, as a measure of skewness, were typically negative: for the whole sample, $\beta$ was -0.47 , significantly different from zero at the $99 \%$ confidence level. Tentatively, they point to time variance in the skewness parameter.

These findings broadly confirm those of Miles and McCue (1984) and Hartzell etal. (1986) who find evidence of non-normality in terms of skewness and kurtosis, and Myer and Webb (1994) who provide evidence of non-normal kurtosis and autocorrelation in private real estate returns. In similar vein, Byrne and Lee (1997) test quarterly returns for sector/region disaggregations of the NCREIF index between 1983 and 1994. Although the number of observations is comparatively small, normality is rejected using the Jarque Bera test for ten of the sixteen sub-sectors. Consistent with earlier findings, they detect positive kurtosis and, typically, negative skewness. They suggest that if returns are best characterised by stable Paretian distributions with infinite variance, portfolio optimisation strategies using the variance as a measure of risk are inappropriate. Instead, they propose use of the mean absolute deviation.

Graff et al. (1997) examine the distributional characteristics of Australian real estate based on the Property Council of Australia's Performance Index. This index i llustrates many of the problems of working with direct real estate data, in that there is only a short time series (1984-1996), low frequency (annual) data, just over 500 properties in the sample (and hence the likelihood of market tracking error) and the capital 
component of the returns is based on valuations rather than transactions. As with Young and Graff (op cit.), McCulloch's method is used to test distributional parameters of individual property return residuals after removal of the time-specific property-type return. The mean alpha parameter, at 1.59 is significantly below the value of 2.0 characteristic of a normal distribution. The betas do not give any clear indication of skewness (nor, in contrast to Young and Graff's US results do they appear to be time variant). The $\mathrm{C}$ parameter, as a proxy for risk, suggests both heteroscedasticity and time variance.

\section{The Public, Indirect Real Estate Market}

The public, or indirect, real estate market consists largely of shares in listed property vehicles. A distinction must be drawn between distributed earnings vehicles such as Real Estate Investment Trusts (REITs) and more conventional real estate companies. The former are vehicles whereby all income after deduction of management charges, is distributed to shareholders. They are frequently tax transparent and, hence, subject to restrictions on investment policy and behaviour-for example, there may be strict limitations on debt to equity ratios. Property companies, by contrast, are able to retain earnings: return thus comes from dividend payments and any share price appreciation. Real estate companies may be further sub-divided into property investment companies and developer-traders. The latter are typically valued on a price-earnings ratio basis, have higher gearing ratios and generally exhibit higher betas than property investment companies whose share price is based on discounted net asset value.

The behaviour of exchange traded real estate securities is, in many ways, more similar to that of other equities (particularly small capitalisation stocks) than of the underlying private real estate. Certainly, reported contemporaneous correlations between traded real estate and stock indices are far higher than those between the direct property market and either stocks or traded real estate. This has led some to question whether there is a separate real estate factor at all, or whether traded property stocks represent a pure property play. This is explored further in the next section. More recent evidence suggests closer links between REITs and the underlying property market. It is thus reasonable to treat their returns as representative of some form of property market performance. Nonetheless, research on the distribution of 
indirect real estate returns produces results that are consistent with stock market research: that is, with non-normality, peaked distributions and fat tails.

Lizieri and Satchell (1997) examined the distribution of monthly property company returns in the UK between 1972 and 1992. They found strong evidence of nonnormality, with Jarque-Bera tests rejecting the null hypothesis at 0.001 and beyond. Returns exhibited positive skewness and kurtosis and were fat-tailed. Equity market returns in general (proxied by the FT All Share index) were similarly non-normal. The residual stock series resulting from an orthogonalisation based on regressing stock returns on property returns $\left(\right.$ FTAS $_{t}=\alpha+\beta$ FTPROP $\left._{t}+v_{t}\right)$ appeared much closer to $(\log )$ normality.

Sieler et al. (1999) examine the return distributions of equity real estate investment trusts (EREITs) for quarterly data from 1986 to 1996. The Kolmogorov-Smirnov, Shapiro-Wilks and Lilliefors tests generally reject normality, despite the small number of observations. By sector, Office REIT returns appear the least normal, while the tests do not reject normality for Industrial REITs. The office returns are characterised by very high volatility, a low mean return and positive skewness. Comparative figures for the direct market show office property returns exhibiting negative skewness, a disturbing contradiction. Myer and Webb (1993) analyse quarterly returns from a small sample of REITs over the period 1978-1990. While a composite index of REITs shows no evidence of non-normality, individual REITs have significant skewness and kurtosis and are non-normal by at least one of the normality tests employed. As with Sieler et al., comparative direct market returns are shown to be non-normal.

Lu and Mei (1999) provide comparative evidence of return distributions for property sector share indices in ten emerging markets. Hampered by short time-series, they apply Anderson-Darling normality tests which weakly reject normality in four of the ten markets. As with the common stocks in those markets, the real estate returns are fat tailed and positively kurtotic. Kurtosis is greater in monthly than in quarterly data which they take as implying that there are abnormal jumps in the return series that are not persistent and are masked in higher frequency data. Interestingly, for portfolio 
strategy purposes, they find that cross-market correlations are increasingly positive when US market conditions are poor - that is “you get diversification when you don't need it".

Almost all the studies of REIT and property company returns report very low autocorrelation coefficients. Typically, in monthly data, the first order coefficient is significant and negative (see, for example, Nelling and Gyourko, 1998), possibly indicating some sort form of mean reversion, but others are non-significant. This contrasts sharply with evidence from the private market where positive serial correlation is marked in sub-annual data and persistent. As previously noted, this pattern is generally attributed to measurement issues or to appraiser behaviour (but see Lai and Wang, 1998 for a contrary view).

\section{A Property Factor? Real Estate and Capital Market Integration}

A key question to be confronted in considering indirect real estate returns is are they stock or property? This question has been the subject of c onsiderable research. This question is embedded within a broader issue: is there a separate real estate factor? If so, is that property factor priced? As with the distributional issues covered above, analysis is made complex by the nature of real estate data.

Many researchers have noted that REIT and property company share returns have much closer contemporaneous correlations with the stock market than with the underlying real estate market. Typical coefficients range between 0.65-0.85 Correlations between the listed real estate securities and the underlying market are generally much lower and are frequently indistinguishable from zero. These results hold even where researchers have attempted to correct for appraisal smoothing in the direct property market and for gearing (leverage) in the indirect, public market series (see, for example, Barkham and Geltner, 1995). Gordon and Canter (1999) suggest (on the basis of rolling correlations) that there is international evidence that real estate stocks are behaving less like stocks and more like property: particularly where the firm is a distributed earnings vehicle, like a REIT. In the US, they show rolling 36 
month correlations between REITs and the stock market falling from over 0.75 in 1990 to under 0.30 in 1998.

Barkham and Geltner (1985) suggest that there is price discovery between the direct and indirect markets in both the US and the UK. They suggest, on the basis of Granger causality tests, that the public market leads the private market, implying that information is impounded into prices more efficiently in exchange-traded markets. Wang et al. (1997) demonstrate cointegration between public and private markets with, again, price discovery from the indirect to the direct market. Monthly private property returns are predictable using lagged values of public and private returns. Whether such predictability could be used profitably given transaction costs and illiquidity on the direct market is moot. Long-run cointegration between real estate and stock markets is demonstrated by Okunev \& Wilson (1997) and Wilson et al. (1998). However, portfolio diversification and arbitrage opportunities rest, critically, on short-term differences and adjustment processes.

Other research has addressed the issue of the integration of real estate markets with other capital markets. Such research typically tests whether there is a separately priced property factor or whether risk factors are similarly priced in real estate and other markets. As such, they are joint tests of market integration and the asset pricing model employed. Thus, for example, Liu et al.(1990) orthogonalise property returns and find that they are priced in the stock market. However, the result is dependent on the validity of the single index, CAPM framework employed. A range of studies are reviewed in Corgelet al. (199) and in Ling and Naranjo (1999). The consensus seem to be that indirect real estate markets are integrated with other capital markets but direct property markets are segmented.

Ling and Naranjo, op cit., employ a multi-factor risk model to test whether risk premia are priced in the same way across US asset markets. They test a variety of private and public market real estate indices. With constant risk premia, they are unable to reject the null hypothesis that real estate stocks and non-property stocks are priced in the same way. However, direct real estate returns appear to be priced differently. With time varying premia, these results broadly hold. Integration is 
accepted in $80 \%$ of quarters for the exchange-listed real estate returns but rejected for the vast majority of direct market returns.

Such results are somewhat troubling. The performance of the listed real estate securities is ultimately dependent upon the underlying private market in that the asset values of the firms depend upon the capital value of the real estate owned, the ability to pay dividends depends upon the net operating income from the property and the ability to trade profitably depends on increases in capital values which, in turn, depend on rental change and expectations of future growth. As a result, a close link between markets might be expected. Yet differences persist even after correction for serial correlation in the direct market and gearing effects in the public market. The standard explanation is that appraisals are failing to respond to market changes and, as a result, returns from valuation-based indices are an inadequate proxy of market performance. However intuitively appealing, this remains an assertion. It is also possible that misunderstanding of the nature of the property market has led to mispricing in the public markets. The evidence of price discovery from public to private markets gives some support for the former thesis but is not conclusive.

\section{Non-Linearity in Real Estate Returns}

The bulk of published real estate research on return distributions has been confined to testing for normality or fitting single distributions. However, there is a small body of work that has examined non-linearity in returns. These studies point tentatively to non-linear forms, with implications both for further research and for portfolio strategies.

Lizieri et al. (1998) examine the monthly returns on UK property company shares and US equity REITs using a Threshold Autoregressive (TAR) model. A two regime solution is proposed, with the regimes separated by the level of real interest rates. The results are similar for the two markets. The regime switching model outperforms a linear, autoregressive model. In the US, in the lower interest rate environment, returns are characterised by mean-reverting behaviour about a positive trend. In the higher interest rate environment, returns exhibit a random walk around a falling trend, with values falling with little volatility. UK returns follow the same pattern. The steepness 
of the trend slope and a negative intercept mean that prices fall more sharply in the second regime than they rise in the first, consistent with the Black leverage effect.

Maitland-Smith and Brooks (1999) investigate non-linearity in the UK and US markets, research hampered by the lack of high frequency data. For US markets, they use NCREIF quarterly returns from 1978-1995; in the UK, they use the Jones Lang Wootton quarterly series from 1977-1995 and the IPD Monthly Index, 1987-1995. In all cases, Jarque-Bera, Lilliefors and Shapiro-Wilks tests overwhelmingly reject normality. They argue, in contrast to prevailing views, that this results as much from skewness as kurtosis. Threshold autoregression (again conditioned on real interest rates) indicates two regimes. They then apply a Hamilton-style Markov switching model to the data which, effectively, tests the hypothesis that the returns are generated by a mixture of two (or more) normal distributions. Tests for normality on the returns sorted into regimes are less likely to be rejected although the authors caution against over-interpretation given small sub-sample size.

Ambrose et al. (1992) test for deterministic non-linearity in daily US real estate (REIT) and s tock market returns, using a fractal structure approach. For stock market returns, they are unable to find evidence that would reject a hypothesis that returns follow a random walk, although suggest that returns are non-normal. The REIT series, by contrast, does exhibit significant persistence. However, this was found to be attributable to short-term bias, rather than long-run effects. Similar results are found for other stock market industry groups.

Newell et al. (1996) test Australian property unit trust returns for chaotic behaviour but find little evidence of chaos. They suggest that non-linear stochastic models are more appropriate. Newell and Matysiak (1997) conduct a battery of tests on daily and weekly UK property company returns and conclude that there is little evidence to support any hypothesis of chaotic behaviour, but that there is evidence that the series are non-random and non-linear in nature. Ward and Wu (1994) find evidence of property market "memory" and smoothing in UK property market returns and suggest that returns series may be exhibit fractal integration. In similar vein, Okunev and Wilson (1997) examine the relationship between REIT and stock market series. While conventional (linear) cointegration tests imply that the series are segmented, further 
tests indicate the presence of a non-linear adjustment process between the series, implying fractional integration. However, they note that the adjustment process is protracted, implying diversification potential.

Research into non-linearity, deterministic/chaotic behaviour, fractional integration and other more complex returns behaviour is hampered by data inadequacy. Exchange listed real estate securities are less problematic - although composition changes, alteration to tax and legal structures and survivorship bias must be considered. However, the low frequency, short time series available in the direct market make interpretation of such tests unreliable and require bootstrapping to generate confidence intervals. Nonetheless, the preliminary evidence does suggest that the possibility of non-linear returns structures must be considered in modelling behaviour and defining investment strategies.

\section{The UK Real Estate Market: Models of Return Distributions}

Comparatively little work has been published on fitting theoretical distributions to observed frequency distributions although, as discussed above, several authors have argued against normal distributions. There are, however, several programs, including BestFit and Crystal Ball available that will fit alternative distributions to frequency distributions. In this section we report the results from applying BestFit for Windows ${ }^{4}$ to the sample data.

The data comprised monthly total returns for the series shown in Table 1 for the period from 31 December 1986 to 31 December 1998. The data consist of direct (valuation-based) institutional property returns reported by the Investment Property Databank (IPD) with series for all property and sub-indices for specified regional and sectoral groups of property; property company and construction firm share series; a residual series estimated by orthogonalising property company share performance on the overall equity market; and, for comparison, All Share and Gilt series. The fitting exercise was performed on the whole period and then repeated on the sub-sample March 1988 to December 1998 to avoid the effect of the extreme observations around

\footnotetext{
${ }^{44}$ Palisade Corporation 1993-1996 Copyright.
} 
and immediately following October 1987. It is, of course, arguable that the returns in that short period October 1987 to February 1988 revealed relevant and even important information about the behaviour of the returns from investments in the long run. It is also plausible that the returns in that period would distort the curve-fitting process if used in the comparatively small sample of 132 returns.

The BestFit program offers 37 different distributions but many of these are inappropriate on a priori grounds. There are only five distributions that are (a) continuous and (b) open-ended at both high and low ends ${ }^{5}$. These are Extreme Value, Error function, Logistic, Normal and Student's t distribution.

The Extreme Value distribution, often associated with Gumbel (1958), is found in three forms although the first is by far the most common. It has been used in a wide range of applications from earthquake magnitudes (Fahmi and Abbasi, 1991), horse racing (Henery, 1984) and the stock market (Wiggins, 1991). The Distribution function is given by:

$$
F(x)=e^{-\frac{\frac{-x-a}{b}}{b}},-\infty<x<\infty, b>0
$$

where $a=$ mode, the mean is given by $a-b \Gamma^{\prime}(1)$ and the standard deviation is $b \pi / \sqrt{ } 6$

The Error function is also known as the exponential power distribution and is symmetric but can be leptokurtic or platykurtic depending on the shape parameter $\mathrm{c}$. Its probability density function is given by

$f(x)=\frac{e^{\frac{-|x-a|^{2 / c}}{2 b}}}{b^{0.5} 2^{c / 2} \Gamma(1+c / 2)},-\infty<\mathrm{x}<\infty, \mathrm{b}>0, \mathrm{c}>0$

where mean $=a$, variance $=\left[2^{c} b^{2} \Gamma(3 c / 2)\right] / \Gamma(c / 2)$.

If $a=0$ and $b=c=1$, then the error function corresponds to a standard normal variate.

\footnotetext{
${ }^{5}$ In principle, the lower bound should be -1 , but the variability of the frequency distributions would not suggest any fixed lower bound.
} 
The Logistic distribution is not commonly used in modelling returns but may be appropriate for modelling the returns of indices because one possible use suggested in the program includes " ... the approximation of the midrange of a set of variables with the same distribution. For example, the average of the minimum and maximum prices brought by identical items at auction." (BestFit, 1998). The probability distribution is given by:

$$
f(x)=\frac{e^{\frac{-(x-a)}{b}}}{b\left(1+e^{\frac{-(x-a)}{b}}\right)^{2}}
$$

where $\mathrm{a}=$ mean and $\mathrm{k}=\pi \mathrm{b} / \sqrt{ } 3=$ standard deviation.

The t-distribution has been used in modelling returns and more specifically ratios (McLeay, 1986) and includes the Normal distribution as a member. The probability distribution is given by:

$$
f(x ; v)=\frac{\{\Gamma[(v+1) / 2]\}}{\sqrt{\pi \omega} \Gamma(v / 2)\left[1+\left(\frac{x^{2}}{v}\right)\right]^{(v+1) / 2}} ;-\infty<x<\infty, v=1,2, \ldots
$$

where $\mathrm{v}$ is a positive integer. The $\mathrm{t}$-distribution is symmetrical and the kurtosis is given by $3(\mathrm{v}-2) /(\mathrm{v}-4)$ for $\mathrm{v}>4$.

There are fourteen other distributions that have specific lower end boundaries. One can justify using these distributions since the lower bound of a returns distribution is1 or $-100 \%$ in any one period. However, the program will also fit any distribution to a sample by appropriate transformation. For example, the Chi-Squared distribution has a lower bound of zero but can be fitted to data that includes the minimum value of 0.5 by adding 0.5 to every observation and then subtracting 0.5 from the fitted ChiSquared value. In the following analysis we report the three distributions highest in the list ranked by the goodness of fit to the empirical data.

There are three tests used to test the goodness of fit of the theoretical distributions: the Chi-Square test, the Kolmogorov-Smirnov and the Anderson-Darling test. The 
ranking is carried out using each test in turn and the goodness-of-fit tests are carried out for every distribution.

The results of this analysis of the FT-All Share index show first how sensitive is the fitting process to outlying observations. When the full sample is used, all tests for normality reject the hypothesis that the normal distribution is an adequate fit of the observed returns. Instead we find that the suggested distributions are Beta and Logistic, with the Weibull being narrowly rejected at the 0.05 level. Of these three, only the Logistic remains untransformed. The transformation of the Weibull involves the addition of 1.22 to the returns: the fit may be almost acceptable using the Kolmogorov-Smirnov test but it has no rationale. Similarly the Beta distribution fitting involves a transformation of dividing the returns by 2.26 and then adding 1.22 to the result. For the sub-sample, the normal is not rejected by the chi-square test and is narrowly rejected by the Anderson-Darling test.

In both the full sample and the sub-sample, the Logistic distribution appears the most plausible using all the tests. Figure 1 shows the fitted and observed returns for the FTAll Share Index from March 1988 to December 1998. Appendix Table A1 provides comparable analysis for a long-term Government bond index whilst Appendix Table A2 summarises the results for the two FT-A sector indices (Construction and Property). In all cases, the diagnostic tests provide similar support for the Logistic and Normal distributions: particularly in the case of the construction sector.

\subsection{Direct Property Indices}

Table 3 presents the results for the IPD monthly index. The index consists of properties held by funds which all have valuations at monthly intervals. Because the distribution of properties in this index differs sharply from the IPD Annual index (having too few City Offices, for example), it can be argued that it is not representative of the institutional property market but, by definition, the portfolios consist of properties that are of "institutional quality". The results are reasonably consistent with those for the other assets, the logistic and normal distributions adequately describe the returns distributions of property. The Beta and Gamma 
distributions are revealed to fit the distributions only after adding 0.0209 to the monthly returns.(to both the returns in the full sample and the sub-sample).

To counter the smoothing problem, discussed above, the analysis is repeated using returns unsmoothed using a simple regression procedure. These results are presented in Table 4. Unfortunately, the results are not supportive of the process of unsmoothing. One of the reasons for unsmoothing the returns from the property indices is the wish to create an indicator that will be more responsive to market information than the appraisal-based valuations. One would therefore suppose that the unsmoothed series would be closer than the unadjusted series to a Normal Distribution; a result that would be consistent with the Weak Form of the Efficient Market Hypothesis. However, in comparing Table 3 and Table 4, we find that the unsmoothed series appear to be less easily modelled than the raw (smoothed) series.

In examining Figure 2, which presents the differences between a Normal distribution and the unsmoothed returns from the IPD Monthly Index, we find that the actual returns, even after adjustment, contain too many returns about zero and too few larger negative and positive returns. This might be expected in a thinly-traded market in which prices move only in response to new company-specific (here, property specific) information and in which that information arrives only infrequently. This corresponds to behavioural studies of valuer behaviour. In other words, the unsmoothing procedure does not correct for the thinness of the trading in the property market.

\subsection{The Sub-Sector Direct Property Indices}

The analysis for various sub-sectors of the IPD Monthly Index (for geographical and sector groupings of properties) are summarised in Table 5 to Table 7 . Because the direct property indices do not exhibit the structural break in October 1987 that was so obvious in the equity markets, the analysis is carried out on the full samples only. It can be seen from Table 5 and Table 6 that, as with the IPD Monthly Index, the unsmoothing procedure makes very little difference to the fit of plausible distributions. Overall, the most appropriate distribution appears to the Logistic distribution - but even here it is rejected in most cases (generally having a probability of around 0.025). As before, the main reason for the inappropriate fit is the excess of returns around zero. In descriptive diagnostics, this is revealed in the measurement of 
kurtosis. This is sharply revealed in Table 8, which summarises the kurtosis of the property sector indices and compares the measures to their theoretical counterparts. In all cases, the kurtosis of the empirical distribution is substantially higher than implied by the respective distribution. By contrast to the direct property indices, the residual series from regression of property company share returns on the all share index (shown in Table 5) appears easier to model, with the normal shown as the favoured distribution.

\subsection{Quarterly Returns}

If the atypical behaviour of property returns can be explained by the thinness of the market and the lack of liquidity and trading, we should expect to see the distributions to conform more closely with other market returns over longer trading intervals. We therefore converted the returns of the direct property indices (unsmoothed) to quarterly returns and re-estimated the distributions. The results are summarised in Table 7 and are consistent with this interpretation. In comparing Table 5 and Table 7 we find that normality is rejected for all five selected sub-sectors of the IPD (Unadjusted) Monthly Property indices but accepted for two of the five sub-sectors of the Quarterly index with a third being narrowly rejected. The logistic distribution is not rejected in two of the monthly indices and is not rejected in any of the quarterly indices although the results of the different significance tests do not always agree. Specifically, the Chi-squared test differs most from the Kolmogorov-Smirnov and the Anderson-Darling tests, albeit not in any systematic way.

It was not appropriate to estimate returns over any longer interval because the small sample properties of the tests would lead to inconclusive results. However, we infer that as the trading interval is increased, the behaviour of the property indices would conform more closely to the returns from other capital markets.

\section{Conclusions}

The empirical results presented above support the existing real estate literature in emphasising that it is unsafe to assume normality of property returns. For the unadjusted IPD monthly data, normality was rejected by a number of test procedures 
while other distributions - notably the logistic - were favoured. When sub-sector returns were analysed, normality was rejected in almost all cases. This, allied to the fact that the distribution of property returns appears to behave in a different way from those of equities and bonds (and, indeed, of securitised real estate), has implications for asset allocation. The inclusion of real estate returns, especially when measured over small intervals, alongside other asset classes in optimising procedures may produce misleading results.

The aberrant behaviour of real estate returns has often been attributed to the appraisalbased nature of capital returns and the problem of valuation smoothing. It has been asserted that unsmoothing the data will result in a returns series that impounds data more rapidly and, hence, produce returns distributions closer to those that would be expected in an informationally efficient market. The evidence here does not support that contention. Unsmoothing the returns does not result in returns distributions that are easier to model or that conform to normality. It appears that this results from the high proportion of returns that are close to zero. We argue that this is a result of the thinly traded market and slow arrival of information, resulting in static individual valuations.

If our inference were correct, real estate markets should produce returns that are more similar to those in other asset markets over longer trading and analysis periods. The analysis of quarterly data is consistent with this view. Returns are easier to model and the normal distribution is favoured on an number of tests both for the aggregate index and at sub-sector level. We suspect that, were there longer time series, still better results could be achieved with annual data. This is consistent with the longer holding periods that characterise investment property (themselves a response to the different structure of the property market, in particular greater specific risk and uncertainty and higher transaction costs). Again, this may cause problems for a formal quantitative mixed asset allocation procedure where the model demands higher frequency data.

Finally, we emphasise that risk and return characteristics of real estate differ from other asset classes. The heterogeneity, indivisibility and large lot size of the assets, the thinly-traded market, the importance of valuations rather than transactions in determining returns and the high transaction costs that drive longer holding periods all 
have an impact on the return structure. As a result, great care must be taken in analysing and interpreting real estate returns and in using these returns in optimised allocations for mixed-asset portfolios. 
Ambrose, B, E Ancel and M Griffiths (1992) The Fractal Structure of Real Estate Investment Trust Returns Journal of the American Real Estate and Urban Economics Association 20, 25-54

Ball M, C Lizieri and B MacGregor (1998) The Economics of Commercial Property Markets London, Routledge

Barkham R and D Geltner (1994) Unsmoothing British Valuation-Based Returns Without Assuming an Efficient Market Journal of Property Research 11, 81-95

Barkham R and D Geltner (1995) Price Discovery in American and British Property Markets Journal of the American Real Estate and Urban Economics Association 23, 21-44

Blundell G and C Ward (1987) Property Portfolio Allocation: A Multifactor Model Land Development Studies 4, 145-156

Brooks C and S Tsolacos (1999) The Impact of Economic and Financial Factors on UK Property Performance Journal of Property Research 16, 139-152

Brown G (1991) Property Investment and the Capital Markets London: E and FN Spon

Brown G (1992) Valuation Accuracy: Developing the Economic Issues Journal of Property Research 9, 199-207

Byrne P and S Lee (1997) Real Estate Portfolio Analysis Under Conditions of NonNormality: The Case of NCREIF Journal of Real Estate Portfolio Management 3, 37-46

Corgel J, W McIntosh and S Ott (1995) Real Estate Investment Trusts: A Review of the Financial Economics Literature Journal of Real Estate Literature 3, 13-43

Evans M, N Hastings \& B Peacock (1993) Statistical Distributions $2^{\text {nd }}$ edition, New York, John Wiley \& Sons

Fahmi K and J Al Abbasi (1991) Application of a Mixture Distribution of Extreme Values to Earthquake Magnitudes in Iraq and Conterminous Regions Geophysical Journal of the Royal Astronomical Society 107, 209-217

Fisher J, D Geltner and B Webb (1994) Value Indices of Commercial Real Estate: A Comparison of Index Construction Methods Journal of Real Estate Finance and Economics 9, 137-164

Geltner D (1991) Smoothing in Appraisal Based Returns Journal of the American Real Estate and Urban Economics Association 13, 15-31

Geltner D (1993) Estimating Market Values from Appraised Values Without Assuming an Efficient Market Journal of Real Estate Research 8, 325-345

Graff R, A Harrington and M Young (199x) The Shape of Australian Real Estate Returns Journal of Real Estate Research 14, 291-308

Gumbel E (1958) Statistics of Extreme Distributions New York: Columbia University Press

Gyourko J and D Keim (1992) What Does the Stock Market Tell Us About Real Estate Returns? Journal of the American Real Estate and Urban Economics Association 20, 457-486

Hartzell, D, J Hekman and M Miles (1986) Diversification Categories in Investment Real Estate Journal of the American Real Estate and Urban Economics Association 14, 230-254

Henery R (1984) An Extreme-Value Model for Predicting the Results of Horse Races Applied Statistics, 33, 125-133 
Johnson N, S Kotz \& Balakrishnan (1995) Continuous Univariate Distributions Volumes 1 \& 2 New York: John Wiley \& Sons

Lai T-Y and K Wang (1998) Appraisal Smoothing: The Other Side of the Story Real Estate Economics 26, 511-535

Liu C, D Hartzell and T Grissom (1990) The Integration of the Real Estate Market and the Stock Market, Some Preliminary Evidence Journal of Real Estate Finance and Economics 3, 261-282

Lizieri C and S Satchell (1997a) Interactions Between Property and Equity Markets: An Investigation of the Linkages in the United Kingdom 1972-1992 Journal of Real Estate Finance and Economics 15, 11-26

Lizieri C and S Satchell (1997b) Property Company Performance and Real Interest Rates: A Regime Switching Approach Journal of Property Research 14, 85-97

Lizieri C, S Satchell, E Worzala and R Dacco' (1998) Real Interest Regimes and Real Estate Performance: A Comparison of US and UK Markets Journal of Real Estate Research 16, 339-356

Lizieri C and P Venmore-Rowland (1993) Valuations, Prices and the Market: A Rejoinder Journal of Property Research 10 77-84

Maitland-Smith J and C Brooks (1999) Threshold Autoregressive and Markov Switching Models: An Application to Commercial Real Estate Journal of Property Research 16, 1-20

Matysiak G and P Wang (1995) Commercial Property Market Prices and Valuations: Analysing the Correspondence Journal of Property Research 12, 181-202

McCue T and J Kling (1994) Real Estate Returns and the Macro-Economy: Some Empirical Evidence Journal of Real Estate Research 9, 277-287

McLeay S (1986) Student's t and the Distribution of Financial ratios Journal of Business, Finance and Accounting 13/2, 209-222

Miles M and T McCue (1984) Commercial Real Estate Returns Journal of the American Real Estate and Urban Economics Association 12, 335-277

Myer N and J Webb (1993) Return Properties of Equity REITs, Common Stocks and Commercial Real Estate Journal of Real Estate Research 8, 87-106

Myer N and J Webb (1994) Statistical Properties of Returns: Financial Assets versus Commercial Real Estate Journal of Real Estate Finance and Economics 8, 267 282

Nelling E and J Gyourko (1998) The Predictability of Equity REIT ReturnsJournal of Real Estate Research 16, 251-268

Newell G and G Matysiak (1997) An Empirical Investigation into the Presence of Chaotic Behaviour in UK Property Markets Royal Institution of Chartered Surveyors Research Report, London: RICS Books.

Newell G, M Peat and M Stevenson (1996) Testing for Evidence of Non-Linear Structure in Australian Real Estate Market Returns, Working Paper \#61, Univesity of Technology, Sydney, Australia

Okunev J and P Wilson (1997) Using Non-Linear Tests to Examine Integration Between Real Estate and Stock Markets Real Estate Economics 25, 487-503

Quan D and J Quigley (1989) Inferring an Investment Return Series for Real Estate from Observations on Sales Journal of the American Real Estate and Urban Economics Association 17, 218-230

Quan D and J Quigley (1991) Price formation and the Appraisal Function in Real Estate Markets Journal of Real Estate Finance and Economics 4, 127-146

Quan D and S Titman (1999) Do Real Estate Markets and Stock Prices Move Together? An International Analysis Real Estate Economics 27, 183-207 
Ross S and R Zisler (1991) Risk and Return in Real Estate Journal of Real Estate Finance and Economics 4, 175-190

Seiler M, J Webb and N Myer (1999) Are EREITs Real Estate? Journal of Real Estate Portfolio Management 5, 171-181

Ward C and W Wu (1994) The Valuation Smoothing Effects on Property Returns: Does the Market Have a Memory? Proceedings, The Cutting Edge Property Research Conference 45-68, London, RICS

Wiggins J (1991) Empirical Tests of the Bias and Efficiency of the Extreme Variance Estimator for Common Stocks Journal of Business of the University of Chicago 64, 417-432

Young M and R Graff (1995) Real Estate is Not Normal: A Fresh Look at Real Estate Return Distributions Journal of Real Estate Finance and Economics 10, 223259 
Table 1: Description of Data-set used in the Distribution-Fitting Exercise ${ }^{6}$.

\begin{tabular}{|l|l|}
\hline FTALL & FT-All Share Return Index, End Month Value, Log Difference \\
\hline Gilts & Medium Dated Gilts, Return Index, Log Difference \\
\hline RPI & Retail Price Index (Headline), Log Difference \\
\hline FT-RealEstate & FT-Real Estate Sector Return Index (Spliced), Log Difference \\
\hline FT-Construct & FT-Construction Sector Index, Log Difference \\
\hline IPDMI & IPD Monthly Returns Index, Log Difference \\
\hline IPDCityOff & IPD City Offices Return Index, Log Difference \\
\hline IPDSEInd & IPD South East Industrial Return Index, Log Difference \\
\hline IPDSERet & IPD South East Retail Return Index, Log Difference \\
\hline IPDMWInd & IPD Midland \& Wales Industrial Return Index, Log Difference \\
\hline IPDNScOff & IPD Northern \& Scottish Office Index, Log Difference \\
\hline Resid1 & Residuals from FTProp = alpha + beta FTALL R-bar-sq = 0.605, beta =1.013 (.068) \\
\hline IPDMIUns & IPD Monthly Returns Unsmoothed (purged of first order autocorrelation) \\
\hline IPDCOUns & IPD City Offices Returns Unsmoothed (purged of first order autocorrelation) \\
\hline IPDSEIndUns & IPD South East Industrial Returns Unsmoothed (purged of first order autocorrelation) \\
\hline IPDSERetUns & IPD South East Retail Returns Unsmoothed (purged of first order autocorrelation) \\
\hline IPDMWIndUns & IPD Midland \& Wales Industrial Returns Unsmoothed (purged of first order autocorrelation) \\
\hline IPDNScoOffUns & IPD Northern \& Scottish Office Returns Unsmoothed (purged of first order autocorrelation) \\
\hline
\end{tabular}

\footnotetext{
${ }^{6}$ Unsmoothing is achieved by regressing $X_{t}$ on $X_{t-1}$ and using the beta to remove the autocorrelation, that is $X^{*}=\left(X_{t}-\beta X_{t-1}\right) /(1-\beta)$ This leaves the means (almost) unchanged but results in an increase in the standard deviation of around $4 \mathrm{x}$ for the whole index and somewhere between 1.7 and 2.9 for the sector/regions. Betas lie in the range $0.57-0.85$. Other unsmoothing methods have been suggested in the literature: it is unlikely that their adoption would alter the results significantly.
} 
Table 2: Distribution of FT-All Share Index

\begin{tabular}{|c|c|c|c|c|c|}
\hline & \multicolumn{5}{|c|}{ Distributions, Ranked by likelihood. } \\
\hline $\begin{array}{l}\text { Test } \mathrm{Full} \\
\text { Sample }\end{array}$ & \multicolumn{3}{|c|}{$\begin{array}{l}\text { Unrestricted fitting (including transformed } \\
\text { distributions) }\end{array}$} & $\begin{array}{l}\text { Open-ended } \\
\text { distributions }\end{array}$ & $\begin{array}{l}\text { Goodness of Fit } \\
\text { Result }\end{array}$ \\
\hline Chi-Square & $\begin{array}{l}\text { Weibull } \\
\text { Rejected }\end{array}$ & $\begin{array}{l}\text { Logistic } \\
\text { Rejected }\end{array}$ & $\begin{array}{l}\text { Beta } \\
\text { Rejected }\end{array}$ & $\begin{array}{l}\text { Error function, } \\
\text { Logistic } \\
\text { Normal } \\
\text { Student's t } \\
\text { Extreme Value }\end{array}$ & $\begin{array}{l}\text { Rejected } \\
\text { Rejected } \\
\text { Rejected } \\
\text { Rejected } \\
\text { Rejected }\end{array}$ \\
\hline $\begin{array}{l}\text { Kolmogorov- } \\
\text { Smirnov }\end{array}$ & $\begin{array}{l}\text { Weibull } \\
\text { Rejected }\end{array}$ & $\begin{array}{l}\text { Logistic } \\
>0.1\end{array}$ & $\begin{array}{l}\text { Beta } \\
\text { Rejected }\end{array}$ & $\begin{array}{l}\text { Error function, } \\
\text { Logistic } \\
\text { Normal } \\
\text { Student's t } \\
\text { Extreme Value }\end{array}$ & $\begin{array}{l}\text { Rejected } \\
>0.1 \\
\text { Rejected } \\
\text { Rejected } \\
\text { Rejected }\end{array}$ \\
\hline $\begin{array}{l}\text { Anderson- } \\
\text { Darling }\end{array}$ & $\begin{array}{l}\text { Logistic } \\
>0.15\end{array}$ & $\begin{array}{l}\text { Weibull } \\
\text { Rejected }\end{array}$ & $\begin{array}{l}\text { Beta } \\
>0.05\end{array}$ & $\begin{array}{l}\text { Error function, } \\
\text { Logistic } \\
\text { Normal } \\
\text { Student's t } \\
\text { Extreme Value }\end{array}$ & $\begin{array}{l}\text { Rejected } \\
>0.15 \\
\text { Rejected } \\
\text { Rejected } \\
\text { Rejected }\end{array}$ \\
\hline \multicolumn{6}{|l|}{ Sub-Sample } \\
\hline Chi-Square & $\begin{array}{l}\text { Logistic } \\
>0.28\end{array}$ & $\begin{array}{l}\text { Normal } \\
>0.23\end{array}$ & $\begin{array}{l}\text { Weibull } \\
>0.14\end{array}$ & $\begin{array}{l}\text { Error function } \\
\text { Logistic } \\
\text { Normal } \\
\text { Student's t } \\
\text { Extreme Value }\end{array}$ & $\begin{array}{l}\text { Rejected } \\
>0.28 \\
>0.23 \\
\text { Rejected } \\
\text { Rejected }\end{array}$ \\
\hline $\begin{array}{l}\text { Kolmogorov- } \\
\text { Smirnov }\end{array}$ & $\begin{array}{l}\text { Logistic } \\
>0.15\end{array}$ & $\begin{array}{l}\text { Extreme Value } \\
\text { Rejected }\end{array}$ & $\begin{array}{l}\text { Normal } \\
\text { Rejected }\end{array}$ & $\begin{array}{l}\text { Error function, } \\
\text { Logistic } \\
\text { Normal } \\
\text { Student's t } \\
\text { Extreme Value }\end{array}$ & $\begin{array}{l}\text { Rejected } \\
>0.15 \\
\text { Rejected } \\
\text { Rejected } \\
\text { Rejected }\end{array}$ \\
\hline $\begin{array}{l}\text { Anderson- } \\
\text { Darling }\end{array}$ & $\begin{array}{l}\text { Logistic } \\
>0.15\end{array}$ & $\begin{array}{l}\text { Normal } \\
\text { Rejected }\end{array}$ & $\begin{array}{l}\text { Weibull } \\
\text { Rejected }\end{array}$ & $\begin{array}{l}\text { Error function, } \\
\text { Logistic } \\
\text { Normal } \\
\text { Student's t } \\
\text { Extreme Value }\end{array}$ & $\begin{array}{l}\text { Rejected } \\
>0.15 \\
\text { Rejected } \\
\text { Rejected } \\
\text { Rejected }\end{array}$ \\
\hline
\end{tabular}

Note: In this and subsequent tables, the figures in the body of the table approximate to the probability that the empirical distribution may be described by the theoretical distribution. Where that probability is below 0.05 , the distributional form is rejected. The appearance of the Weibull and Beta distributions may seem odd since both are restricted to positive values. In fitting the distributions, however, the software transforms the values by adding to $\boldsymbol{\alpha}$ multiplying by constants. Whilst the distributions may have some empirical descriptive power, they can not be inferred to have economic plausibility. 
Table 3: Distribution of Returns from IPD Monthly Property Index

\begin{tabular}{|c|c|c|c|c|c|}
\hline & \multicolumn{5}{|c|}{ Distributions, Ranked by likelihood. } \\
\hline $\begin{array}{l}\text { Test } \mathrm{Yull} \\
\text { Sample }\end{array}$ & \multicolumn{3}{|c|}{$\begin{array}{l}\text { Unrestricted fitting (including } \\
\text { transformed distributions) }\end{array}$} & $\begin{array}{l}\text { Open-ended } \\
\text { distributions }\end{array}$ & $\begin{array}{l}\text { Goodness of } \\
\text { Fit Result }\end{array}$ \\
\hline Chi-Square & $\begin{array}{l}\text { Logistic } \\
>0.59\end{array}$ & $\begin{array}{l}\text { Normal } \\
>0.47\end{array}$ & $\begin{array}{l}\text { Weibull } \\
>0.47\end{array}$ & $\begin{array}{l}\text { Error function, } \\
\text { Logistic } \\
\text { Normal } \\
\text { Student's t } \\
\text { Extreme Value }\end{array}$ & $\begin{array}{l}\text { Rejected } \\
>0.59 \\
>0.47 \\
\text { Rejected } \\
\text { Rejected }\end{array}$ \\
\hline $\begin{array}{l}\text { Kolmogorov- } \\
\text { Smirnov }\end{array}$ & $\begin{array}{l}\text { Normal } \\
>0.15\end{array}$ & $\begin{array}{l}\text { Beta } \\
>0.15\end{array}$ & $\begin{array}{l}\text { Weibull } \\
>0.1\end{array}$ & $\begin{array}{l}\text { Error function, } \\
\text { Logistic } \\
\text { Normal } \\
\text { Student's t } \\
\text { Extreme Value }\end{array}$ & $\begin{array}{l}\text { Rejected } \\
>0.15 \\
>0.15 \\
\text { Rejected } \\
\text { Rejected }\end{array}$ \\
\hline $\begin{array}{l}\text { Anderson- } \\
\text { Darling }\end{array}$ & $\begin{array}{l}\text { Beta } \\
>0.15\end{array}$ & $\begin{array}{l}\text { Gamma } \\
>0.15\end{array}$ & $\begin{array}{l}\text { Erlang } \\
>0.15\end{array}$ & $\begin{array}{l}\text { Error function, } \\
\text { Logistic } \\
\text { Normal } \\
\text { Student's t } \\
\text { Extreme Value }\end{array}$ & $\begin{array}{l}\text { Rejected } \\
>0.15 \\
\text { Rejected } \\
\text { Rejected } \\
\text { Rejected }\end{array}$ \\
\hline Sub-Sample & & & & & \\
\hline Chi-Square & $\begin{array}{l}\text { Logistic } \\
>0.25\end{array}$ & $\begin{array}{l}\text { Gamma } \\
>0.23\end{array}$ & $\begin{array}{l}\text { Weibull } \\
>0.17\end{array}$ & $\begin{array}{l}\text { Error function } \\
\text { Logistic } \\
\text { Normal } \\
\text { Student's t } \\
\text { Extreme Value }\end{array}$ & $\begin{array}{l}\text { Rejected } \\
>0.25 \\
>0.13 \\
\text { Rejected } \\
\text { Rejected }\end{array}$ \\
\hline $\begin{array}{l}\text { Kolmogorov- } \\
\text { Smirnov }\end{array}$ & $\begin{array}{l}\text { Beta } \\
>0.15\end{array}$ & $\begin{array}{l}\text { Weibull } \\
>0.05\end{array}$ & $\begin{array}{l}\text { Erlang } \\
>0.15\end{array}$ & $\begin{array}{l}\text { Error function, } \\
\text { Logistic } \\
\text { Normal } \\
\text { Student's t } \\
\text { Extreme Value }\end{array}$ & $\begin{array}{l}\text { Rejected } \\
>0.1 \\
\text { Rejected } \\
\text { Rejected } \\
\text { Rejected }\end{array}$ \\
\hline $\begin{array}{l}\text { Anderson- } \\
\text { Darling }\end{array}$ & $\begin{array}{l}\text { Beta } \\
>0.15\end{array}$ & $\begin{array}{l}\text { Erlang } \\
>0.15\end{array}$ & $\begin{array}{l}\text { Gamma } \\
>0.15\end{array}$ & $\begin{array}{l}\text { Error function, } \\
\text { Logistic } \\
\text { Normal } \\
\text { Student's t } \\
\text { Extreme Value }\end{array}$ & $\begin{array}{l}\text { Rejected } \\
>0.1 \\
\text { Rejected } \\
\text { Rejected } \\
\text { Rejected }\end{array}$ \\
\hline
\end{tabular}


Table 4: Distribution of Returns from IPD Monthly Property Index (Unsmoothed)

\begin{tabular}{|c|c|c|c|c|c|}
\hline & \multicolumn{5}{|c|}{ Distributions, Ranked by likelihood. } \\
\hline $\begin{array}{l}\text { Test Full } \\
\text { Sample }\end{array}$ & \multicolumn{3}{|c|}{$\begin{array}{l}\text { Unrestricted fitting (including } \\
\text { transformed distributions) }\end{array}$} & $\begin{array}{l}\text { Open-ended } \\
\text { distributions }\end{array}$ & $\begin{array}{l}\text { Goodness of } \\
\text { Fit Result }\end{array}$ \\
\hline Chi-Square & $\begin{array}{l}\text { Logistic } \\
\text { Rejected }\end{array}$ & $\begin{array}{l}\text { Error Function } \\
\text { Rejected }\end{array}$ & $\begin{array}{l}\text { Triangular } \\
\text { Rejected }\end{array}$ & $\begin{array}{l}\text { Error function, } \\
\text { Logistic } \\
\text { Normal } \\
\text { Student's t } \\
\text { Extreme Value }\end{array}$ & $\begin{array}{l}\text { Rejected } \\
\text { Rejected } \\
\text { Rejected } \\
\text { Rejected } \\
\text { Rejected }\end{array}$ \\
\hline $\begin{array}{l}\text { Kolmogorov- } \\
\text { Smirnov }\end{array}$ & $\begin{array}{l}\text { Logistic } \\
>0.15\end{array}$ & $\begin{array}{l}\text { ExtremeValue } \\
\text { Rejected }\end{array}$ & $\begin{array}{l}\text { Normal } \\
\text { Rejected }\end{array}$ & $\begin{array}{l}\text { Error function, } \\
\text { Logistic } \\
\text { Normal } \\
\text { Student's t } \\
\text { Extreme Value }\end{array}$ & $\begin{array}{l}\text { Rejected } \\
>0.15 \\
\text { Rejected } \\
\text { Rejected } \\
\text { Rejected }\end{array}$ \\
\hline $\begin{array}{l}\text { Anderson- } \\
\text { Darling }\end{array}$ & $\begin{array}{l}\text { Logistic } \\
>0.15\end{array}$ & $\begin{array}{l}\text { Normal } \\
\text { Rejected }\end{array}$ & $\begin{array}{l}\text { Beta } \\
\text { Rejected }\end{array}$ & $\begin{array}{l}\text { Error function, } \\
\text { Logistic } \\
\text { Normal } \\
\text { Student's t } \\
\text { Extreme Value }\end{array}$ & $\begin{array}{l}\text { Rejected } \\
>0.15 \\
\text { Rejected } \\
\text { Rejected } \\
\text { Rejected }\end{array}$ \\
\hline Sub-Sample & & & & & \\
\hline Chi-Square & $\begin{array}{l}\text { Logistic } \\
\text { Rejected }\end{array}$ & $\begin{array}{l}\text { Error Function } \\
\text { Rejected }\end{array}$ & $\begin{array}{l}\text { Triangular } \\
\text { Rejected }\end{array}$ & $\begin{array}{l}\text { Error function } \\
\text { Logistic } \\
\text { Normal } \\
\text { Student's t } \\
\text { Extreme Value }\end{array}$ & $\begin{array}{l}\text { Rejected } \\
\text { Rejected } \\
\text { Rejected } \\
\text { Rejected } \\
\text { Rejected }\end{array}$ \\
\hline $\begin{array}{l}\text { Kolmogorov- } \\
\text { Smirnov }\end{array}$ & $\begin{array}{l}\text { Logistic } \\
>0.15\end{array}$ & $\begin{array}{l}\text { Extreme Value } \\
\text { Rejected }\end{array}$ & $\begin{array}{l}\text { Normal } \\
\text { Rejected }\end{array}$ & $\begin{array}{l}\text { Error function, } \\
\text { Logistic } \\
\text { Normal } \\
\text { Student's t } \\
\text { Extreme Value }\end{array}$ & $\begin{array}{l}\text { Rejected } \\
>0.15 \\
\text { Rejected } \\
\text { Rejected } \\
\text { Rejected }\end{array}$ \\
\hline $\begin{array}{l}\text { Anderson- } \\
\text { Darling }\end{array}$ & $\begin{array}{l}\text { Logistic } \\
>0.1\end{array}$ & $\begin{array}{l}\text { Normal } \\
\text { Rejected }\end{array}$ & $\begin{array}{l}\text { Beta } \\
\text { Rejected }\end{array}$ & $\begin{array}{l}\text { Error function, } \\
\text { Logistic } \\
\text { Normal } \\
\text { Student's t } \\
\text { Extreme Value }\end{array}$ & $\begin{array}{l}\text { Rejected } \\
>0.1 \\
\text { Rejected } \\
\text { Rejected } \\
\text { Rejected }\end{array}$ \\
\hline
\end{tabular}


Table 5: Distribution of Returns from IPD Monthly Sub-Sector Indices (Unadjusted)

\begin{tabular}{|c|c|c|c|c|}
\hline & & \multicolumn{3}{|c|}{ Goodness of Fit Results } \\
\hline & $\begin{array}{l}\text { Open-ended } \\
\text { distributions }\end{array}$ & IPDCityOff & IPDSERet & $\overline{I P D N S c O f f}$ \\
\hline Chi-Square & $\begin{array}{l}\text { Error function, } \\
\text { Logistic } \\
\text { Normal } \\
\text { Student's t } \\
\text { Extreme Value }\end{array}$ & $\begin{array}{l}\text { Rejected } \\
\text { Rejected } \\
\text { Rejected } \\
\text { Rejected } \\
\text { Rejected }\end{array}$ & $\begin{array}{l}\text { Rejected } \\
\text { Rejected } \\
\text { Rejected } \\
\text { Rejected } \\
\text { Rejected }\end{array}$ & $\begin{array}{l}\text { Rejected } \\
\text { Rejected } \\
\text { Rejected } \\
\text { Rejected } \\
\text { Rejected }\end{array}$ \\
\hline $\begin{array}{l}\text { Kolmogorov- } \\
\text { Smirnov }\end{array}$ & $\begin{array}{l}\text { Error function, } \\
\text { Logistic } \\
\text { Normal } \\
\text { Student's t } \\
\text { Extreme Value }\end{array}$ & $\begin{array}{l}\text { Rejected } \\
>0.1 \\
\text { Rejected } \\
\text { Rejected } \\
\text { Rejected }\end{array}$ & $\begin{array}{l}\text { Rejected } \\
\text { Rejected } \\
\text { Rejected } \\
\text { Rejected } \\
\text { Rejected }\end{array}$ & $\begin{array}{l}\text { Rejected } \\
\text { Rejected } \\
\text { Rejected } \\
\text { Rejected } \\
\text { Rejected }\end{array}$ \\
\hline $\begin{array}{l}\text { Anderson- } \\
\text { Darling }\end{array}$ & $\begin{array}{l}\text { Error function, } \\
\text { Logistic } \\
\text { Normal } \\
\text { Student's t } \\
\text { Extreme Value }\end{array}$ & $\begin{array}{l}\text { Rejected } \\
\text { Rejected } \\
\text { Rejected } \\
\text { Rejected } \\
\text { Rejected }\end{array}$ & $\begin{array}{l}\text { Rejected } \\
\text { Rejected } \\
\text { Rejected } \\
\text { Rejected } \\
\text { Rejected }\end{array}$ & $\begin{array}{l}\text { Rejected } \\
\text { Rejected } \\
\text { Rejected } \\
\text { Rejected } \\
\text { Rejected }\end{array}$ \\
\hline & & IPDSEInd & IPDMWInd & Residl \\
\hline Chi-Square & $\begin{array}{l}\text { Error function, } \\
\text { Logistic } \\
\text { Normal } \\
\text { Student's t } \\
\text { Extreme Value }\end{array}$ & $\begin{array}{l}\text { Rejected } \\
\text { Rejected } \\
\text { Rejected } \\
\text { Rejected } \\
\text { Rejected }\end{array}$ & $\begin{array}{l}\text { Rejected } \\
\text { Rejected } \\
\text { Rejected } \\
\text { Rejected } \\
\text { Rejected }\end{array}$ & $\begin{array}{c}>0.07 \\
>0.08 \\
>0.09 \\
\text { Rejected } \\
\text { Rejected }\end{array}$ \\
\hline $\begin{array}{l}\text { Kolmogorov- } \\
\text { Smirnov }\end{array}$ & $\begin{array}{l}\text { Error function, } \\
\text { Logistic } \\
\text { Normal } \\
\text { Student's t } \\
\text { Extreme Value }\end{array}$ & $\begin{array}{l}\text { Rejected } \\
\text { Rejected } \\
\text { Rejected } \\
\text { Rejected } \\
\text { Rejected }\end{array}$ & $\begin{array}{l}\text { Rejected } \\
\text { Rejected } \\
\text { Rejected } \\
\text { Rejected } \\
\text { Rejected }\end{array}$ & $\begin{array}{c}>0.15 \\
>0.1 \\
>0.05 \\
\text { Rejected } \\
\text { Rejected }\end{array}$ \\
\hline $\begin{array}{l}\text { Anderson- } \\
\text { Darling }\end{array}$ & $\begin{array}{l}\text { Error function, } \\
\text { Logistic } \\
\text { Normal } \\
\text { Student's t } \\
\text { Extreme Value }\end{array}$ & $\begin{array}{l}\text { Rejected } \\
\text { Rejected } \\
\text { Rejected } \\
\text { Rejected } \\
>0.05\end{array}$ & $\begin{array}{l}\text { Rejected } \\
\text { Rejected } \\
\text { Rejected } \\
\text { Rejected } \\
\text { Rejected }\end{array}$ & $\begin{array}{c}>0.15 \\
>0.1 \\
>0.05 \\
\text { Rejected } \\
\text { Rejected }\end{array}$ \\
\hline
\end{tabular}


Table 6: Distribution of Returns from IPD Monthly Sub-Sector Indices (Unsmoothed)

\begin{tabular}{|c|c|c|c|c|}
\hline & & \multicolumn{3}{|c|}{ Goodness of Fit Result } \\
\hline & $\begin{array}{l}\text { Open-ended } \\
\text { distributions }\end{array}$ & IPDCOUns & IPDSERetUns & IPDNScoOffUns \\
\hline Chi-Square & $\begin{array}{l}\text { Error function, } \\
\text { Logistic } \\
\text { Normal } \\
\text { Student's t } \\
\text { Extreme Value }\end{array}$ & $\begin{array}{l}\text { Rejected } \\
\text { Rejected } \\
\text { Rejected } \\
\text { Rejected } \\
\text { Rejected }\end{array}$ & $\begin{array}{l}\text { Rejected } \\
\text { Rejected } \\
\text { Rejected } \\
\text { Rejected } \\
>0.05\end{array}$ & $\begin{array}{l}\text { Rejected } \\
\text { Rejected } \\
\text { Rejected } \\
\text { Rejected } \\
\text { Rejected }\end{array}$ \\
\hline $\begin{array}{l}\text { Kolmogorov- } \\
\text { Smirnov }\end{array}$ & $\begin{array}{l}\text { Error function, } \\
\text { Logistic } \\
\text { Normal } \\
\text { Student's t } \\
\text { Extreme Value }\end{array}$ & $\begin{array}{l}\text { Rejected } \\
\text { Rejected } \\
\text { Rejected } \\
\text { Rejected } \\
\text { Rejected }\end{array}$ & $\begin{array}{l}\text { Rejected } \\
\text { Rejected } \\
\text { Rejected } \\
\text { Rejected } \\
>0.05\end{array}$ & $\begin{array}{l}\text { Rejected } \\
\text { Rejected } \\
\text { Rejected } \\
\text { Rejected } \\
\text { Rejected }\end{array}$ \\
\hline $\begin{array}{l}\text { Anderson- } \\
\text { Darling }\end{array}$ & $\begin{array}{l}\text { Error function, } \\
\text { Logistic } \\
\text { Normal } \\
\text { Student's t } \\
\text { Extreme Value }\end{array}$ & $\begin{array}{l}\text { Rejected } \\
\text { Rejected } \\
\text { Rejected } \\
\text { Rejected } \\
\text { Rejected }\end{array}$ & $\begin{array}{l}\text { Rejected } \\
\text { Rejected } \\
\text { Rejected } \\
\text { Rejected } \\
>0.05\end{array}$ & $\begin{array}{l}\text { Rejected } \\
\text { Rejected } \\
\text { Rejected } \\
\text { Rejected } \\
\text { Rejected }\end{array}$ \\
\hline & & IPDSEIndUns & IPDMWIndUns & \\
\hline Chi-Square & $\begin{array}{l}\text { Error function, } \\
\text { Logistic } \\
\text { Normal } \\
\text { Student's t } \\
\text { Extreme Value }\end{array}$ & $\begin{array}{l}\text { Rejected } \\
\text { Rejected } \\
\text { Rejected } \\
\text { Rejected } \\
\text { Rejected }\end{array}$ & $\begin{array}{l}\text { Rejected } \\
\text { Rejected } \\
\text { Rejected } \\
\text { Rejected } \\
\text { Rejected }\end{array}$ & \\
\hline $\begin{array}{l}\text { Kolmogorov- } \\
\text { Smirnov }\end{array}$ & $\begin{array}{l}\text { Error function, } \\
\text { Logistic } \\
\text { Normal } \\
\text { Student's t } \\
\text { Extreme Value }\end{array}$ & $\begin{array}{l}\text { Rejected } \\
>0.15 \\
\text { Rejected } \\
\text { Rejected } \\
\text { Rejected }\end{array}$ & $\begin{array}{l}\text { Rejected } \\
>0.15 \\
\text { Rejected } \\
\text { Rejected } \\
\text { Rejected }\end{array}$ & \\
\hline $\begin{array}{l}\text { Anderson- } \\
\text { Darling }\end{array}$ & $\begin{array}{l}\text { Error function, } \\
\text { Logistic } \\
\text { Normal } \\
\text { Student's t } \\
\text { Extreme Value }\end{array}$ & $\begin{array}{l}\text { Rejected } \\
>0.15 \\
\text { Rejected } \\
\text { Rejected } \\
\text { Rejected }\end{array}$ & $\begin{array}{l}\text { Rejected } \\
>0.1 \\
\text { Rejected } \\
\text { Rejected } \\
\text { Rejected }\end{array}$ & \\
\hline
\end{tabular}


Table 7: Distribution of Quarterly Returns from IPD Sub-Sector Indices (Unadjusted)

\begin{tabular}{|c|c|c|c|c|}
\hline & & \multicolumn{3}{|c|}{ Goodness of Fit Result } \\
\hline & $\begin{array}{l}\text { Open-ended } \\
\text { distributions }\end{array}$ & IPDCityOff & IPDSERet & $I P D N S c O f f$ \\
\hline Chi-Square & $\begin{array}{l}\text { Error function, } \\
\text { Logistic } \\
\text { Normal } \\
\text { Student's t } \\
\text { Extreme Value }\end{array}$ & $\begin{array}{c}>0.20 \\
>0.50 \\
>0.44 \\
\text { Rejected } \\
\text { Rejected }\end{array}$ & $\begin{array}{l}\text { Rejected } \\
\quad>0.09 \\
>0.09 \\
\text { Rejected } \\
\text { Rejected }\end{array}$ & $\begin{array}{c}\text { Rejected } \\
\text { Rejected } \\
\text { Rejected } \\
\text { Rejected } \\
>0.07\end{array}$ \\
\hline $\begin{array}{l}\text { Kolmogorov- } \\
\text { Smirnov }\end{array}$ & $\begin{array}{l}\text { Error function, } \\
\text { Logistic } \\
\text { Normal } \\
\text { Student's t } \\
\text { Extreme Value }\end{array}$ & $\begin{array}{l}\text { Rejected } \\
>0.15 \\
\text { Rejected } \\
\text { Rejected } \\
\text { Rejected }\end{array}$ & $\begin{array}{l}\text { Rejected } \\
\quad>0.15 \\
>0.15 \\
\text { Rejected } \\
\text { Rejected }\end{array}$ & $\begin{array}{c}\text { Rejected } \\
>0.15 \\
\text { Rejected } \\
\text { Rejected } \\
>0.05\end{array}$ \\
\hline $\begin{array}{c}\text { Anderson- } \\
\text { Darling }\end{array}$ & $\begin{array}{l}\text { Error function, } \\
\text { Logistic } \\
\text { Normal } \\
\text { Student's t } \\
\text { Extreme Value }\end{array}$ & $\begin{array}{c}\text { Rejected } \\
>0.15 \\
\text { Rejected } \\
\text { Rejected } \\
\text { Rejected } \\
\end{array}$ & $\begin{array}{c}\text { Rejected } \\
>0.15 \\
>0.10 \\
\text { Rejected } \\
>0.05 \\
\end{array}$ & $\begin{array}{l}\text { Rejected } \\
\quad>0.10 \\
\text { Rejected } \\
\text { Rejected } \\
\text { Rejected }\end{array}$ \\
\hline & & IPDSEInd & IPDMWInd & $I P D M I$ \\
\hline Chi-Square & $\begin{array}{l}\text { Error function, } \\
\text { Logistic } \\
\text { Normal } \\
\text { Student's t } \\
\text { Extreme Value }\end{array}$ & $\begin{array}{l}\text { Rejected } \\
\text { Rejected } \\
\text { Rejected } \\
\text { Rejected } \\
>0.30\end{array}$ & $\begin{array}{l}\text { Rejected } \\
\quad>0.05 \\
\text { Rejected } \\
\text { Rejected } \\
>0.50\end{array}$ & $\begin{array}{c}\text { Rejected } \\
\quad>0.07 \\
>0.13 \\
\text { Rejected } \\
\text { Rejected }\end{array}$ \\
\hline $\begin{array}{l}\text { Kolmogorov- } \\
\text { Smirnov }\end{array}$ & $\begin{array}{l}\text { Error function, } \\
\text { Logistic } \\
\text { Normal } \\
\text { Student's t } \\
\text { Extreme Value }\end{array}$ & $\begin{array}{c}\text { Rejected } \\
>0.15 \\
\text { Rejected } \\
\text { Rejected } \\
\text { Rejected }\end{array}$ & $\begin{array}{c}\text { Rejected } \\
>0.15 \\
\text { Rejected } \\
\text { Rejected } \\
>0.15\end{array}$ & $\begin{array}{c}\text { Rejected } \\
>0.15 \\
>0.15 \\
\text { Rejected } \\
>0.10\end{array}$ \\
\hline $\begin{array}{l}\text { Anderson- } \\
\text { Darling }\end{array}$ & $\begin{array}{l}\text { Error function, } \\
\text { Logistic } \\
\text { Normal } \\
\text { Student's t } \\
\text { Extreme Value }\end{array}$ & $\begin{array}{l}\text { Rejected } \\
\quad>0.15 \\
\text { Rejected } \\
\text { Rejected } \\
>0.05\end{array}$ & $\begin{array}{l}\text { Rejected } \\
\quad>0.15 \\
\text { Rejected } \\
\text { Rejected } \\
>0.10\end{array}$ & $\begin{array}{c}\text { Rejected } \\
\quad>0.15 \\
>0.15 \\
\text { Rejected } \\
>0.15\end{array}$ \\
\hline
\end{tabular}


Table 8: Kurtosis of Actual Property Returns, Compared with Model Distributions

\begin{tabular}{|l|c|c|c|c|c|c|}
\hline Returns & & & & & & \\
\hline Actual & $\begin{array}{c}\text { Error } \\
\text { Function }\end{array}$ & Logistic & Normal & Student'st & $\begin{array}{c}\text { Extreme } \\
\text { Value }\end{array}$ \\
\hline IPD Monthly & 3.34 & 3.0 & 4.2 & 3.0 & 3.0 & 5.4 \\
\hline $\begin{array}{l}\text { IPD Monthly } \\
\text { Unsmoothed }\end{array}$ & 6.24 & 3.0 & 4.2 & 3.0 & 3.0 & 5.4 \\
\hline $\begin{array}{l}\text { City Offices } \\
\text { Unsmoothed }\end{array}$ & 8.72 & 3.0 & 4.2 & 3.0 & 3.0 & 5.4 \\
\hline $\begin{array}{l}\text { SE Offices } \\
\text { Unsmoothed }\end{array}$ & 8.49 & 3.0 & 4.2 & 3.0 & 3.0 & 5.4 \\
\hline $\begin{array}{l}\text { SE Retail } \\
\text { Unsmoothed }\end{array}$ & 15.0 & 3.0 & 4.2 & 3.0 & 3.0 & 5.4 \\
\hline $\begin{array}{l}\text { MW Industrials } \\
\text { Unsmoothed }\end{array}$ & 7.34 & 3.0 & 4.2 & 3.0 & 3.0 & 5.4 \\
\hline $\begin{array}{l}\text { N Scot Offices } \\
\text { Unsmoothed }\end{array}$ & 4.62 & 3.0 & 4.2 & 3.0 & 3.0 & 5.4 \\
\hline
\end{tabular}


Figure 1: Fitted and Observed Returns for FT-All Share Index $(3 / 88-12 / 98)$

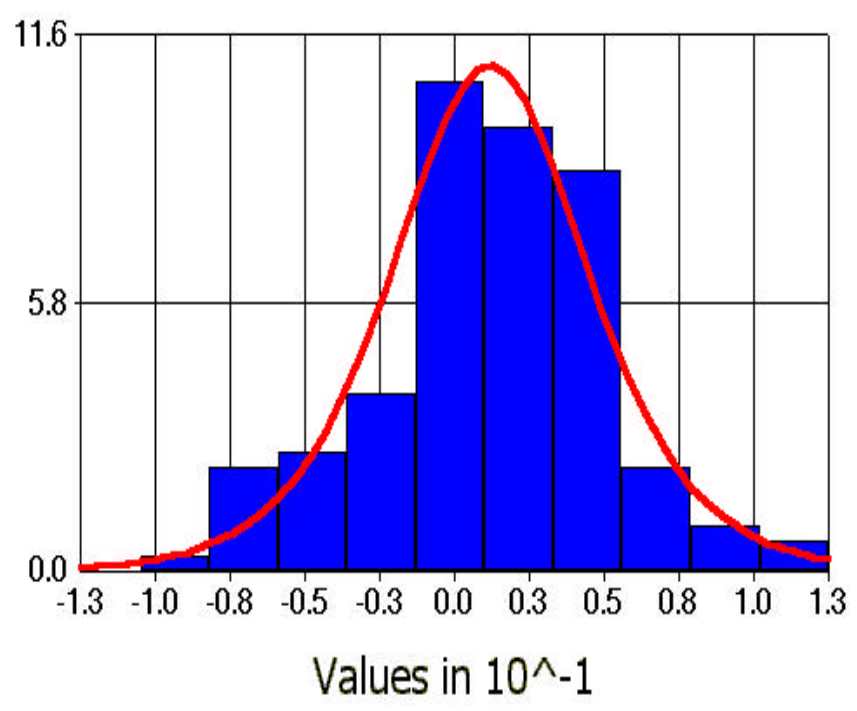


Figure 2: Differences between Normal Distribution and Actual Distribution of IPD Monthly Returns (Unsmoothed) - Negative values imply Actual > Normal

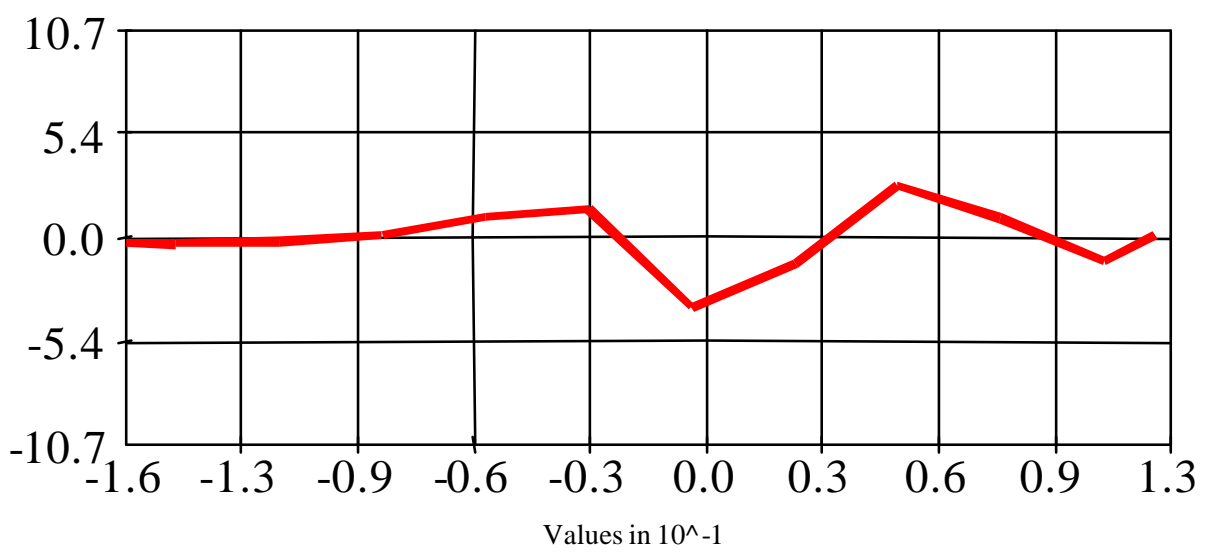


Figure 3: Time Series (Log-Scale) of FT All Share and IPD Property Index

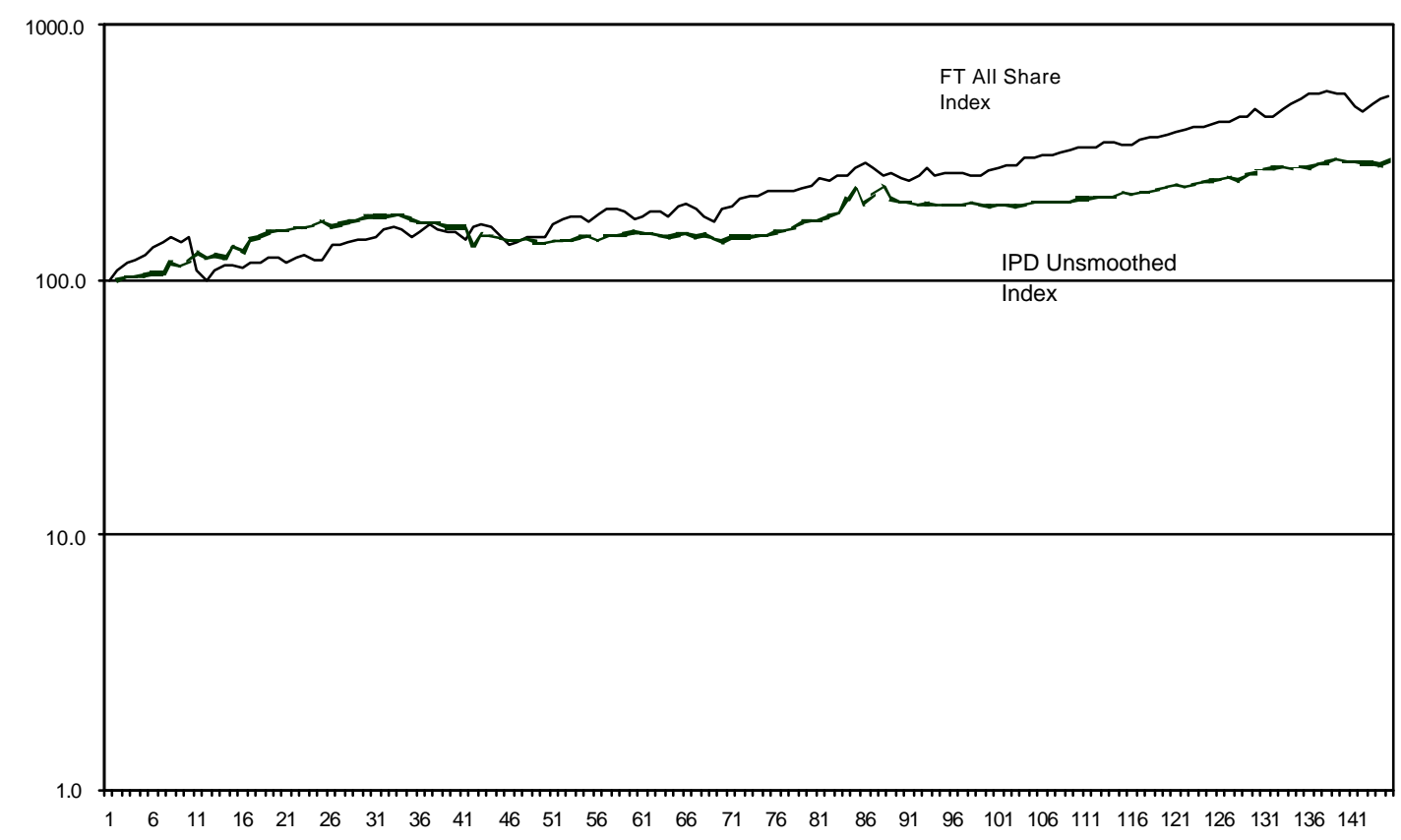




\section{Appendix}

Appendix Table A. 1: Distribution of UK Government Bond (medium term) returns.

\begin{tabular}{|c|c|c|c|c|c|}
\hline Gilts & \multirow{2}{*}{\multicolumn{3}{|c|}{$\begin{array}{l}\text { Ranked by Likelihood. } \\
\text { Unrestricted fitting (including } \\
\text { transformed distributions) }\end{array}$}} & & \\
\hline $\begin{array}{c}\text { Test } \mathrm{Full} \\
\text { Sample }\end{array}$ & & & & $\begin{array}{l}\text { Open-ended } \\
\text { distributions }\end{array}$ & $\begin{array}{c}\text { Goodness of } \\
\text { Fit Result }\end{array}$ \\
\hline Chi-Square & $\begin{array}{c}\text { Normal } \\
>0.73\end{array}$ & $\begin{array}{c}\text { Logistic } \\
>0.71\end{array}$ & $\begin{array}{c}\text { Triang. } \\
>0.61\end{array}$ & $\begin{array}{l}\text { Error function, } \\
\text { Logistic } \\
\text { Normal } \\
\text { Student's t }\end{array}$ & $\begin{array}{c}\text { Rejected } \\
>0.71 \\
>0.73 \\
\text { Rejected }\end{array}$ \\
\hline $\begin{array}{l}\text { Kolmogorov- } \\
\text { Smirnov }\end{array}$ & $\begin{array}{l}\text { Weibull } \\
>0.1\end{array}$ & $\begin{array}{c}\text { Normal } \\
>0.15\end{array}$ & $\begin{array}{c}\text { Logistic } \\
>0.15\end{array}$ & $\begin{array}{l}\text { Error function, } \\
\text { Logistic } \\
\text { Normal } \\
\text { Student's t } \\
\end{array}$ & $\begin{array}{c}\text { Rejected } \\
>0.15 \\
>0.15 \\
\text { Rejected } \\
\end{array}$ \\
\hline $\begin{array}{l}\text { Anderson- } \\
\text { Darling }\end{array}$ & $\begin{array}{l}\text { Normal } \\
>0.15\end{array}$ & $\begin{array}{l}\text { Logistic } \\
>0.15\end{array}$ & $\begin{array}{l}\text { Weibull } \\
\text { Rejected }\end{array}$ & $\begin{array}{l}\text { Error function, } \\
\text { Logistic } \\
\text { Normal } \\
\text { Student's t }\end{array}$ & $\begin{array}{l}\text { Rejected } \\
>0.15 \\
>0.15 \\
\text { Rejected }\end{array}$ \\
\hline Sub-Sample & & & & & \\
\hline Chi-Square & $\begin{array}{c}\text { Logistic } \\
>0.87\end{array}$ & $\begin{array}{c}\text { Normal } \\
>0.85\end{array}$ & $\begin{array}{l}\text { Triang } \\
>0.59\end{array}$ & $\begin{array}{l}\text { Error function } \\
\text { Logistic } \\
\text { Normal } \\
\text { Student's t }\end{array}$ & $\begin{array}{l}\text { Rejected } \\
\quad>0.87 \\
>0.85 \\
\text { Rejected }\end{array}$ \\
\hline $\begin{array}{l}\text { Kolmogorov- } \\
\text { Smirnov }\end{array}$ & $\begin{array}{c}\text { Weibull } \\
>0.1\end{array}$ & $\begin{array}{c}\text { Normal } \\
>0.15\end{array}$ & $\begin{array}{c}\text { Logistic } \\
>0.15\end{array}$ & $\begin{array}{l}\text { Error function, } \\
\text { Logistic } \\
\text { Normal } \\
\text { Student's t }\end{array}$ & $\begin{array}{l}\text { Rejected } \\
\quad>0.15 \\
>0.15 \\
\text { Rejected }\end{array}$ \\
\hline $\begin{array}{l}\text { Anderson- } \\
\text { Darling }\end{array}$ & $\begin{array}{c}\text { Logistic } \\
>0.15\end{array}$ & $\begin{array}{c}\text { Normal } \\
>0.15\end{array}$ & $\begin{array}{l}\text { Weibull } \\
\text { Rejected }\end{array}$ & $\begin{array}{l}\text { Error function, } \\
\text { Logistic } \\
\text { Normal } \\
\text { Student's t } \\
\end{array}$ & $\begin{array}{l}\text { Rejected } \\
\quad>0.15 \\
>0.15 \\
\text { Rejected }\end{array}$ \\
\hline
\end{tabular}


Appendix Table A. 2: Distribution of FT Sector Indices return

\begin{tabular}{|c|c|c|c|c|c|}
\hline \multicolumn{3}{|c|}{ FT-Real Estate } & \multicolumn{3}{|c|}{ FT-Construct } \\
\hline $\begin{array}{l}\text { Test } \mathrm{Full} \\
\text { Sample }\end{array}$ & $\begin{array}{l}\text { Open-ended } \\
\text { distributions }\end{array}$ & $\begin{array}{l}\text { Goodness of } \\
\text { Fit Result }\end{array}$ & $\begin{array}{l}\text { TestFull } \\
\text { Sample }\end{array}$ & $\begin{array}{l}\text { Open-ended } \\
\text { distributions }\end{array}$ & $\begin{array}{l}\text { Goodness of } \\
\text { Fit Result }\end{array}$ \\
\hline Chi-Square & $\begin{array}{l}\text { Error function, } \\
\text { Logistic } \\
\text { Normal } \\
\text { Student's t }\end{array}$ & $\begin{array}{c}\text { Rejected } \\
>0.14 \\
\text { Rejected } \\
\text { Rejected }\end{array}$ & Chi-Square & $\begin{array}{l}\text { Error function, } \\
\text { Logistic } \\
\text { Normal } \\
\text { Student's t }\end{array}$ & $\begin{array}{c}\text { Rejected } \\
>0.71 \\
>0.73 \\
\text { Rejected }\end{array}$ \\
\hline $\begin{array}{l}\text { Kolmogoro } \\
\text { v-Smirnov }\end{array}$ & $\begin{array}{l}\text { Error function, } \\
\text { Logistic } \\
\text { Normal } \\
\text { Student's t }\end{array}$ & $\begin{array}{c}\text { Rejected } \\
>0.15 \\
>0.05 \\
\text { Rejected }\end{array}$ & $\begin{array}{l}\text { Kolmogorov- } \\
\text { Smirnov }\end{array}$ & $\begin{array}{l}\text { Error function, } \\
\text { Logistic } \\
\text { Normal } \\
\text { Student's t }\end{array}$ & $\begin{array}{c}\text { Rejected } \\
>0.15 \\
>0.15 \\
\text { Rejected }\end{array}$ \\
\hline $\begin{array}{l}\text { Anderson- } \\
\text { Darling }\end{array}$ & $\begin{array}{l}\text { Error function, } \\
\text { Logistic } \\
\text { Normal } \\
\text { Student's t }\end{array}$ & $\begin{array}{l}\text { Rejected } \\
>0.15 \\
\text { Rejected } \\
\text { Rejected }\end{array}$ & $\begin{array}{l}\text { Anderson- } \\
\text { Darling }\end{array}$ & $\begin{array}{l}\text { Error function, } \\
\text { Logistic } \\
\text { Normal } \\
\text { Student's t }\end{array}$ & $\begin{array}{c}\text { Rejected } \\
>0.15 \\
>0.15 \\
\text { Rejected }\end{array}$ \\
\hline $\begin{array}{l}\text { Sub- } \\
\text { Sample }\end{array}$ & & & Sub-Sample & & \\
\hline Chi-Square & $\begin{array}{l}\text { Error function } \\
\text { Logistic } \\
\text { Normal } \\
\text { Student's t }\end{array}$ & $\begin{array}{c}\text { Rejected } \\
>0.87 \\
>0.85 \\
\text { Rejected }\end{array}$ & Chi-Square & $\begin{array}{l}\text { Error function } \\
\text { Logistic } \\
\text { Normal } \\
\text { Student's t }\end{array}$ & $\begin{array}{c}\text { Rejected } \\
>0.87 \\
>0.85 \\
\text { Rejected }\end{array}$ \\
\hline $\begin{array}{l}\text { Kolmogoro } \\
\text { v-Smirnov }\end{array}$ & $\begin{array}{l}\text { Error function, } \\
\text { Logistic } \\
\text { Normal } \\
\text { Student's t }\end{array}$ & $\begin{array}{c}\text { Rejected } \\
>0.15 \\
>0.15 \\
\text { Rejected }\end{array}$ & $\begin{array}{l}\text { Kolmogorov- } \\
\text { Smirnov }\end{array}$ & $\begin{array}{l}\text { Error function, } \\
\text { Logistic } \\
\text { Normal } \\
\text { Student's t }\end{array}$ & $\begin{array}{c}\text { Rejected } \\
>0.15 \\
>0.15 \\
\text { Rejected }\end{array}$ \\
\hline $\begin{array}{l}\text { Anderson- } \\
\text { Darling }\end{array}$ & $\begin{array}{l}\text { Error function, } \\
\text { Logistic } \\
\text { Normal } \\
\text { Student's t }\end{array}$ & $\begin{array}{c}\text { Rejected } \\
>0.15 \\
>0.15 \\
\text { Rejected }\end{array}$ & $\begin{array}{l}\text { Anderson- } \\
\text { Darling }\end{array}$ & $\begin{array}{l}\text { Error function, } \\
\text { Logistic } \\
\text { Normal } \\
\text { Student's t }\end{array}$ & $\begin{array}{c}\text { Rejected } \\
>0.15 \\
>0.15 \\
\text { Rejected }\end{array}$ \\
\hline
\end{tabular}

